\title{
CONCEPT MAPPING AS A STRATEGY TO SCAFFOLD CONCEPT LITERACY IN ACCOUNTING FOR EXTENDED PROGRAMMES
}

\author{
S. Immelman* \\ Language and Study Skills \\ e-mail: susan.immelman@up.ac.za
}

\section{A. Carstens*}

Unit for Academic Literacy

e-mail: adelia.carstens@up.ac.za

\section{S. Smith*}

Department of Accounting

e-mail: sonnette.smith@up.ac.za

\author{
A. Masenge* \\ Department of Statistics \\ e-mail: andries.masenge@up.ac.za \\ *University of Pretoria \\ Pretoria, South Africa
}

\section{ABSTRACT}

While great strides have been made to improve accessibility to higher education in South Africa, successful completion of bachelor's degrees within the prescribed time remains a challenge. Research suggests that a lack of conceptual understanding by students might be at the heart of the problem. This study, which is grounded in Ausubel's Assimilation Theory as applied by Joseph Novak and his colleagues, investigates the value of concept mapping as a scaffolding technique to improve conceptual understanding. The research involved a quasi-experiment with a test and a control group. It was hypothesised that accounting students in an extended programme who had been introduced to the concept mapping technique would demonstrate an improved grasp of accounting concepts, indicated by an improvement in their marks when composing an explanatory paragraph of accounting concepts after a teaching intervention. However, the post-intervention marks of the test group showed no improvement, and therefore no proof can be offered to support the claim that concept mapping improves conceptual understanding. Pre-and post-intervention questionnaires were used to collect data on confounding variables and also to assess student experiences of concept mapping. An analysis of student experiences indicated enthusiasm for the technique. Limitations of the study included the absence of a pilot study and insufficient time to become familiar with concept mapping. An unforeseen constraint on the study was low student participation.

Keywords: concept mapping, concept literacy, throughput, scaffolding, rote learning, meaningful learning, visual aids, extended programme 


\section{INTRODUCTION}

Much has been achieved in higher education to redress the inequalities of the past. From 1994 to 2010 access to higher education increased by 80 per cent; participation by black students increased by 79 per cent during this period. However, student performance and throughput numbers remain a matter of concern (CHE 2015; CHE 2013). Many solutions have been proposed, primarily by means of Government policies (Department of Education 1997; Ministry of Education 2001; DHET 2010; 2011), and various forms of supplementary academic assistance, ranging from add-on modules to fully-fledged foundation programmes (McKenna 2012; Boughey 2010; Volbrecht and Boughey 2004). Thus far the desired improvements have not been achieved, not even by means of extended and foundation programmes (CHE 2015). New initiatives, supported by rigorous research, are needed to address the issues that underlie these concerns.

The research on which we report in this article was aimed at the empirical testing of the effectiveness of a particular support strategy, namely concept mapping. It was hoped that concept mapping would promote concept literacy through a multimodal scaffolded approach. The article provides background information on the underpreparedness of university students, and delineates the need for structural support, especially in the context of extended programmes at a university in Gauteng province, South Africa. It then provides an overview of concept mapping, including its theoretical underpinnings, pedagogical techniques, and main advantages. The next section describes the methodology of the empirical research, followed by the findings, a discussion thereof, and a conclusion in terms of the effectiveness of concept mapping and future research opportunities.

\section{BACKGROUND}

Support for underprepared students has taken many forms over the years. While selective academic support was initially seen as sufficient (Volbrecht and Boughey 2004), more extensive solutions became necessary as access to higher education increased (McKenna 2012; Boughey 2010) and the school system weakened, creating further complications (Jonker 2016). Academic support became known as Academic development (Volbrecht and Boughey 2004) and varied in its application from add-on classes to extended programmes and even adaptation of the conventional curriculum (McKenna 2012; Volbrecht and Boughey 2004).

Despite the focus on and research into the academic support of students, throughput figures remain problematic. According to a CHE report (2015) for the period 2010 to 2015, only 23 per cent of black students completed their three-year degree in that time. Other groups 
fared little better. For coloured students the pass rate was only 25 per cent, for Indian students 27 per cent, and for white students 43 per cent. After six years, only 55 per cent of black students had completed their degree, 51 per cent of coloured students, 61 per cent of Indian students and 65 per cent of white students (CHE 2015). Thus, after twice the regulation time for the degree, only half of previously disadvantaged students had obtained their degrees, and only three-fifths of students from previously advantaged backgrounds.

In spite of the extra support that extended degree programmes provide, the picture is hardly more promising. According to the same CHE report (2015), only two-thirds of students on these programmes managed to obtain their degrees in six years. At the university where the research took place, the Bureau: Institutional Research \& Planning (2016) reports a 2011 throughput rate in regulation time of only 8 per cent for previously disadvantaged students on an extended progaramme. The 2011 throughput rate for white students on the programme was only 14 per cent. Such a low success rate for both previously advantaged and disadvantaged students suggests that the lack of academic success can now be considered a general problem among students, and that there is a dire need for solutions.

A number of studies using a variety of scaffolding tools have been conducted to improve academic success. As part of the Concept Literacy Project which was conducted at the University of Cape Town, Paxton (2009) used multilingual glossaries in combination with translanguaging to improve students' conceptual understanding. The glossaries were created by the students themselves and reflect the range of home languages represented: isiXhosa, isiZulu, Sesotho, Setswana, Sepedi, Afrikaans and English. Madiba (2014) reports the continuation of this project which made use of multimodal online glossaries in conjunction with multilingual tutorials, particularly for mathematics teaching and learning. Jonker (2016) discusses the use of multilingual glossaries (English, Afrikaans and isiXhosa) at the University of Stellenbosch to enhance knowledge of terminology in political sciences in an extended Humanities programme. While her research indicated an improvement in the acquisition of subject-specific vocabulary, written assignments still suggested a lack of conceptual understanding.

Before providing an overview of the research conducted for this study, it is necessary to clarify what is meant by conceptual understanding, or concept literacy. The vocabulary of a discipline consists of specific terms that encapsulate concepts, also referred to as "units of meaning" (Croft and Cruse 2004, 7). For the full meaning of concepts to be grasped, more than their definitions is required. Rather, a conceptual understanding of their actual significance is required (Novak 2010). Concepts do not exist in isolation but are interrelated (Croft and Cruse 2004; Novak 2002), so that when the relationships between concepts of a certain discipline are recognised, an understanding of the discipline itself is the result. Concept literacy can therefore 
be described as being able to understand and use the words and language structures that provide access to a particular discipline (Young, Van der Vlugt and Qanya 2005). This description emphasises the relationship between language and content. According to Gablasova (2012), the mastery of subject-matter includes learning the appropriate way to communicate it. Concept mapping, which forms the basis of this research, is a technique that is specifically designed to facilitate concept literacy. It will be discussed in more detail in the next section.

\section{THEORETICAL UNDERPINNINGS}

\section{Ausubel's Assimilation Theory}

The Assimilation Theory was developed by Ausubel (1962) to explain how the learning process should enable meaningful learning. In the first place he stated that we form concepts in our minds and that, for meaningful learning to take place, the concepts that are created when new information is received must be built onto our prior knowledge structures (Novak 2010; Simon 2007; Safayeni, Derbentseva and Cañas 2005; Ausubel 1962). Secondly, it is important that the prior knowledge a student has on a topic is pertinent to the new information received, as learning can only be meaningful if a student's existing knowledge structures are meaningful (Novak 2010). In the third place, a student should be actively involved in learning for it to have real value (Novak 2010; Novak and Cañas 2008; Carnot et al. 2003). Should students resist the assimilation of new information (Novak 2010) or continue to rely on inadequate study methods such as rote learning, meaningful learning cannot take place, regardless of the learning strategy used or the effort made by the teacher (Novak and Cañas 2008).

Conceptual knowledge structures are described as being hierarchical in nature. Relationships between concepts are recognised by means of subsumption, which, according to Novak (2010), refers to the process of linking the concepts that are least inclusive (and therefore more specific) to the concepts that are most inclusive (and therefore more general). Thus, a network of connections is created and from the many relationships with which a concept is identified, its overall meaning develops. Furthermore, the subsumption process encourages the long-term recall of information, instead of the continued reinforcement required for information acquired through rote learning (Novak 2010).

Because of the importance of creating meaningful knowledge structures in the mind, Ausubel proposes that younger learners be provided with well-constructed examples of the topic being introduced, while more experienced learners should be able to construct such knowledge structures on their own (Nielsen 1980). Moreover, the building of newly acquired concepts onto prior knowledge structures might be particularly difficult for students if their 
knowledge structures are weak (Maas and Leauby 2005). This is often the result of a lack of development of students' creative thinking abilities. To overcome this problem, Ausubel suggests using advance organisers that, when used as pre-learning tasks, will aid students in the scaffolding of knowledge (Novak 2002). In the next section, Ausubel's Assimilation Theory, which strongly focusses on learning that is meaningful through schematised knowledge representation, will be shown as the genesis of concept mapping as a scaffolding technique.

\section{Concept mapping}

Concept mapping is a scaffolding instrument (Chang, Sung and Chen 2002; Novak and Cañas 2008) that visually represents the knowledge hierarchy of a particular topic (Simon 2007; Novak and Cañas 2008; Novak 2010; Greenberg and Wilner 2015) by depicting the relationships between concepts. The premise of the concept mapping technique is that meaningful learning takes place when such interrelationships between concepts are identified (Novak 2002; Carnot et al. 2003; Novak and Cañas 2008), an activity that requires active participation from the student (Maas and Leauby 2005; Simon 2007; Novak and Cañas 2008; Novak 2010; Chabeli 2010). Although other types of visual aids are available, concept mapping is the only such aid that is founded on "the theories of learning and knowledge" (Greenberg and Wilner 2015, 16). Figure 1 illustrates the hierarchical nature of concept mapping (Novak and Cañas 2008; Novak 2010). Concepts are indicated by boxes, with labelled lines linking them to show their interrelationships. The direction of the relationships are indicated by arrows, where necessary. Cañas et al. (2004) suggest the use of software as this eases the creation of concept maps considerably. For this research, CmapTools (available at http://cmap.ihmc.us) was used.

Concept mapping advances learning in several ways. Among others, the structure of concept mapping allows information to be represented in an alternative mode, namely graphic (non-textual) visualisation. Furthermore, Novak and Cañas $(2008,7)$ maintain that the technique is effective because vast areas of knowledge can be scaffolded "piece by piece with small units of interacting concept and propositional frameworks". This atomistic approach is particularly useful in deconstructing complex concepts (Novak 2010). And also in facilitating synthesis by showing how lower-level concepts and their interrelationships constitute an overarching or superordinate concept (Leauby, Szabat and Maas 2010).

A second area in which concept mapping advances the learning process is through student involvement, which, as previously discussed, Ausubel sees as a necessity for meaningful learning to take place (Carnot et al. 2003). When constructing a map, a student's prior knowledge is established (Novak and Cañas 2008). Subsequently, the quality of the relationships identified in the concept map will illustrate whether or not meaningful learning 
has been achieved (Simon 2007). Because knowledge has been made explicit, misconceptions are also rooted out (Novak 2010). When used as a group project, concept mapping encourages interaction and collaboration (Novak and Cañas 2008). Learning is often the result of the "richness and diversity of knowledge, skills, and attitudes" when previous knowledge is pooled (Novak 2010, 173) and students reach consensus about their collective knowledge (Novak 2010). Finally, it is of specific importance to the present study that struggling students may benefit if they are introduced to a structured learning process, such as concept mapping (Simon 2007). A partially completed concept map may, in particular, offer support to struggling students who experience anxiety in learning (Maas and Leauby 2005).

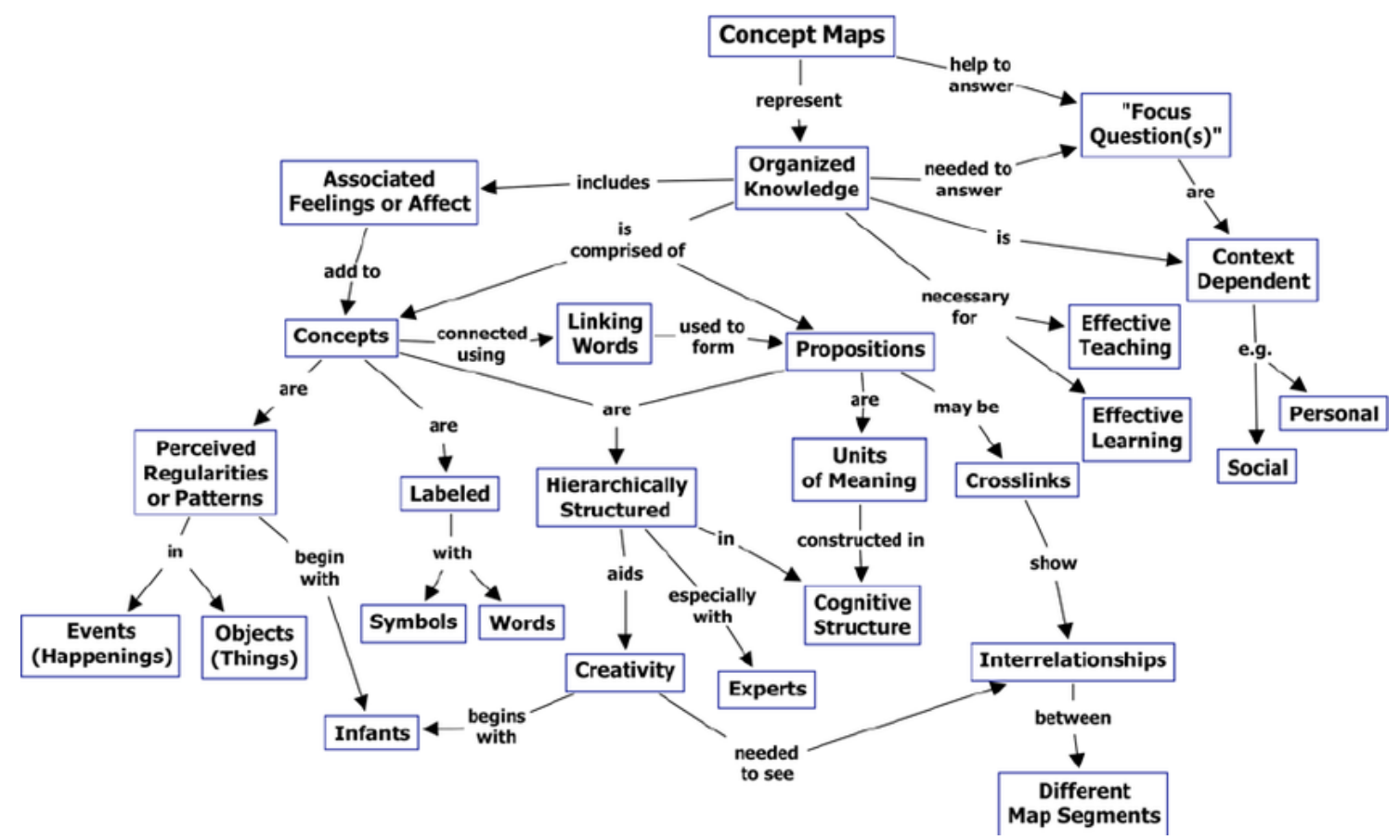

Figure 1: A concept map on the topic of "Concept Maps", from Novak and Cañas (2008)

Another learning advantage of concept mapping is that it develops meta-cognitive abilities, such as comprehension and critical thinking, which not only has a cumulative effect on the value of the learning (Chang et al. 2002), but also facilitates the transfer of cross-domain knowledge, which is one of the desired effects of meaningful learning (Widmayer 2005). Furthermore, the technique supports a variety of learning tasks and may, for example, be used to provide the framework for an upcoming theme (Novak and Gowin 1984), to summarise information and to brainstorm an upcoming task (Leauby et al. 2010).

From the above it is clear that concept mapping could enhance learning in almost all learning areas and across the higher education spectrum. Its use has, among others, been 
documented in health (Brennan et al. 2012), religious studies (Pui-lan 2010), biology (Kinchin 2000), nursing (Clarke 2015), and accounting. This technique is particularly suitable for the teaching of accounting, as, according to Maas and Leauby (2005), accounting students very often revert to rote learning, whereas "the effective use of accounting knowledge is based on a thorough understanding of an integrated conceptual and technical business framework" (Leauby et al. 2010, 284). As reported in the previous section, concept mapping was created to encourage meaningful learning and to enhance critical thinking. In addition to the above, the hierarchical nature of accounting makes concept mapping a suitable teaching and learning strategy (Leauby et al. 2010). The next section provides an overview of previous studies which have looked at using concept mapping in accounting education.

\section{Empirical studies on the effectiveness of concept mapping}

A number of studies confirm that concept mapping is a suitable teaching and learning stategy in the field of accounting education (Maas and Leauby 2005; Simon 2007; Leauby et al. 2010). However, its pedagogical effectiveness in this discipline has not been adequately shown: the studies lack adequate rigour in terms of measurable results, number of participants and consideration of confounding variables (Leauby et al. 2010). Below, the studies by Maas and Leauby (2005), Simon (2007) and Leauby et al. (2010) are discussed in brief.

Maas and Leauby (2005) used concept maps in an introductory accounting module and obtained useful results, suggesting that the technique is worth pursuing. However, the sample size for their research was too small to draw concrete conclusions. Simon (2007) used both partially created and ab initio concept maps with final year accounting students, and established that while the maps of stronger students showed more insight, all participants found the technique both challenging and useful. Simon (2007) observes that Asian students were particularly enthusiastic about the technique, which might suggest that a presentation of knowledge that is not language intensive is more accessible to second-language speakers. However, the students' results were not tested for improvement, and therefore the overall success of the intervention cannot be assumed. In a further study, first-year accounting students were immersed in a concept mapping intervention for a whole year. Their results were then compared with those of a previous year of first-year accounting students who had not had the intervention (Leauby et al. 2010). Although students showed enthusiasm for the technique, there was no measurable improvement in results.

The present study intended to address the existing research gaps by rigorously researching the effectiveness of concept mapping as a scaffolding instrument to enhance concept literacy, and thereby fast track epistemological access in accounting for extended curriculum students. 


\section{Overview of study and research methodology}

\section{Research paradigm, design and strategy}

The present article only gives an account of the quantitative results of a larger study that followed a sequential mixed-methods strategy (Cresswell 2014), within a Postpositivist design (Trochim 2001; Willis 2012). The study was conducted with extended programme accounting students who were divided into a BCom test group or BSc control group. All BCom students in this programme are required to take accounting as a subject, whereas the BSc accounting students have chosen the subject as an elective. Convenience sampling was used, as the choice of test and control group relied on accessibility (Somekh and Lewin 2011). Since the selection of the two groups was not random, this is called a quasi-experimental study (Lewin 2011)

\section{Setting}

The accounting lecturer introduces new concepts during two formal lectures per week. These concepts are reinforced by tutors during four hours of tutorials per week. It was decided that the accounting lecturer would introduce the concept maps, based on previously discussed material, during the lecture periods. The concept mapping intervention was assimilated into the normal curriculum. Furthermore, alignment between the added assessment tools and the desired outcomes of the curriculum was ensured so that the authenticity and validity of assessment was assured (Herrington and Herrington 2006).

The students in the test group were first familiarised with the idea of concept mapping by presenting previously covered topics using this technique. This was done as the technique was entirely new to students and time constraints prevented more extensive immersion. It was further felt that the introduction of concept mapping in a normal lecture period might alleviate any anxiety that students could experience as a result of unfamiliarity with the technique (Carnot et al. 2003). Students were also encouraged to work in pairs or teams of three so that they would have the added support of peer scaffolding (Herrington, Oliver and Reeves 2002). A completed concept map on the theme of revenue (sales), was discussed with students, after which they had to complete a partially constructed concept map on the accounting cycle. For the intervention, the test group students were presented with a partially completed map on the accrual concept in a subsequent class. Afterwards a model map was discussed by the accounting lecturer. The accounting lecturer and the researcher, using CmapTools software (Novak and Cañas 2008), were both involved in the creation of the concept maps. 


\section{Data collection}

Data on student performance were collected by means of explanatory paragraphs, and data on student attitudes by means of questionnaires. The questionnaires were completed in class to counteract the traditionally low response rate associated with this form of data collection. Both groups completed the pre-intervention questionnaire, after which they were required to write the pre-intervention paragraph which had a as subject matter a topic with which they were familiar. Then, once the intervention had taken place, the participants were again required to write a paragraph. The test group was introduced to the theme for the post-intervention paragraph by means of concept mapping. The control group was introduced to the theme by more traditional means. For both paragraphs, real-world accounting scenarios were created that required the application of accounting concepts in their solution. Certain accounting terms were made available to students to aid them in the formulation of their answers. Both paragraph assessments were created by the Accounting Department. The pre- and post-intervention paragraph marks served as quantifiable measurements of learning having taken place.

While students were familiar with an assessment format where accounting principles needed to be applied to real-world scenarios, these assessments differed in their execution in that the solution was required to be written as a paragraph instead of in numerical format. This departure from the more familiar assessment format is justified by research. Vygotsky (1986), Novak (2010) and Novak and Cañas (2008) assert that it is only through the medium of language that the learning of concepts can take place. Pearson, Hiebert and Kamil (2012) claim that effective terminology acquisition can only be proved if such terminology spontaneously appears in students' speaking and writing. The researcher marked the pre- and post-intervention paragraphs and the marking was moderated by the accounting lecturer.

Finally, after the intervention, a questionnaire was completed by the test group. In this case, the questions were aimed at extracting students' experiences of concept mapping, and the questionnaire was therefore not completed by the control group.

\section{Data analysis}

Data analysis was done in four parts. For the first part of the analysis, the confounding variables of the two groups were compared, as well their pre-intervention paragraph marks. Differences between the groups needed to be accounted for as convenience sampling was used to select the groups. For the second part of the analysis, it was necessary to compare the marks of the postintervention paragraph to that of the pre-intervention paragraph for each of the groups to see whether any improvement was evident. For the third part of the analysis, the possible influence of confounding variables on the pre- and post-intervention results of either group was examined. 
Finally, using the data garnered from the post-intervention questionnaire, student experiences of the intervention were analysed.

\section{FINDINGS}

\section{Establishment of comparability of test and control groups}

\section{Comparison of pre-intervention questionnaire responses of test and control groups}

The pre-intervention questionnaire responses of the two groups were compared first. The questionnaire contained questions about students' learning styles (verbal, aural, physical or visual), their familiarity with visual aids (such as mind maps), and demographic information (school attended, level of English in Grade 12, experience of accounting at school, Grade 12 marks for English and mathematics, and the final Admission Points Score (APS), calculated using the Grade 12 exam marks and used to apply for university entry).

The questionnaire responses consisted of both ordinal (Likert scale) responses and categorical variables. For the ordinal variables, similarity of response distribution was examined by means of the non-parametric Mann-Whitney U-test, as the two groups are independent and the participants in the group are unique. The results, as summarised in Table 1 (below), indicate that the medians of the variables are closely grouped. Furthermore, the pvalues are $>0.05$. We can thus deduce that any difference in the responses of the groups is insignificant, which ultimately means that the learning style preferences for both groups were the same.

Table 1: Table of comparison of ordinal pre-intervention questionnaire responses of test and control groups

\begin{tabular}{|l|l|c|c|c|c|c|c|c|}
\hline \multirow{2}{*}{ No } & Question & \multicolumn{3}{|c|}{$\begin{array}{l}\text { Test group (BCom) } \\
\text { (Scaling: strongly agree=1, agree=2, } \\
\text { disagree=3, strongly disagree) }\end{array}$} & \multicolumn{3}{|c|}{$\begin{array}{c}\text { Control group } \\
\text { (BSc) } \mathbf{n = 3 5}\end{array}$} & \multicolumn{1}{c|}{$\begin{array}{c}\mathbf{p}- \\
\text { value }\end{array}$} \\
\cline { 3 - 9 } & $\mathbf{M}$ & $\mathbf{M e d}$ & $\mathbf{S D}$ & $\mathbf{M}$ & $\mathbf{M e d}$ & SD & \\
\hline Q1 & I learn through reading a printed or written text & 1.61 & 2.00 & .708 & 1.66 & 2.00 & .639 & 0.590 \\
\hline Q2 & I learn through listening (e.g. to a lecture). & 2.13 & 2.00 & .779 & 1.97 & 2.00 & .133 & 0.326 \\
\hline Q3 & $\begin{array}{l}\text { I learn when I am active (e.g. when I highlight, } \\
\text { underline, summarise. }\end{array}$ & 1.57 & 1.00 & .693 & 1.77 & 2.00 & .154 & 0.386 \\
\hline Q4 & $\begin{array}{l}\text { I learn by using visual elements (e.g. maps, } \\
\text { graphs, pictures). }\end{array}$ & 2.19 & 2.00 & .937 & 2.34 & 2.00 & .998 & 0.480 \\
\hline
\end{tabular}

As the rest of the variables were categorical values, it was suitable to use cross-tabulation to determine the response distribution. The probability that the observed distribution was a result of chance had to be accounted for; for this reason, Pearson's Chi-square tests were conducted. 
Except for the APS, the resultant p-values were all significant, indicating that the two groups did not have the same backgrounds: students in the test group were more likely to have had previous experience of visual aids, and to have found them useful for memorisation and understanding. Of the test group, only a quarter (25\%) had been in government schools where no fee is paid, whereas almost two-thirds $(60 \%)$ of the control group had been in these schools. This result appears to be linked to the higher percentage of students in the test group who studied English as Home Language at school and also obtained better marks in English in Grade 12, when compared to the students in the control group. Furthermore, a large percentage of students in the test group (71\%) had previous experience of accounting, compared to less than a quarter $(23 \%)$ of the control group. However, as is to be expected from the application requirements for the BSc Mathematical degree, the control group students obtained higher marks in mathematics in Grade 12. Table 2 shows a summary of the results.

Table 2: Table of comparison of categorical variables of pre-intervention questionnaire responses of test and control groups

\begin{tabular}{|c|c|c|c|c|c|c|}
\hline \multirow{2}{*}{ No } & \multirow{2}{*}{ Question } & \multicolumn{2}{|c|}{ Test group (BCom) } & \multicolumn{2}{|c|}{ Control group (BSc) } & \multirow{2}{*}{$\begin{array}{c}\text { p- } \\
\text { value }\end{array}$} \\
\hline & & $\mathrm{n}$ & $\%$ & $\mathbf{n}$ & $\%$ & \\
\hline Q5 & $\begin{array}{l}\text { I have used visual aids, such as the one } \\
\text { shown here, before (yes }=1, \text { no }=2 \text { ). }\end{array}$ & $\begin{array}{l}Y=46 \\
N=24\end{array}$ & $\begin{array}{l}Y=65.7 \\
N=34.3\end{array}$ & $\begin{array}{l}Y=15 \\
N=20\end{array}$ & $\begin{array}{l}\mathrm{Y}=42.9 \\
\mathrm{~N}=57.1\end{array}$ & $.025^{*}$ \\
\hline Q6 & $\begin{array}{l}\text { The visual aid that I used helped me to } \\
\text { MEMORISE the work (yes=1, no=2, not } \\
\text { applicable=3). }\end{array}$ & $\begin{array}{l}Y=40 \\
N=10 \\
N A=20\end{array}$ & $\begin{array}{l}Y=57.1 \\
N=14.3 \\
N A=28.6\end{array}$ & $\begin{aligned} Y & =9 \\
N & =7 \\
N A & =19\end{aligned}$ & $\begin{array}{l}Y=25.7 \\
N=20.0 \\
N A=54.3\end{array}$ & $.008^{* *}$ \\
\hline Q7 & $\begin{array}{l}\text { The visual aid that I used helped me to } \\
\text { UNDERSTAND the work (yes }=1 \text {, no }=2 \text {, not } \\
\text { applicable=3). }\end{array}$ & $\begin{array}{l}Y=37 \\
N=13 \\
N A=20\end{array}$ & $\begin{aligned} Y & =52.9 \\
N & =18.6 \\
N A & =28.6\end{aligned}$ & $\begin{array}{c}Y=14 \\
N=2 \\
N A=19\end{array}$ & $\begin{aligned} Y & =40.0 \\
N & =5.7 \\
N A & =54.3\end{aligned}$ & $.022^{*}$ \\
\hline $\begin{array}{l}\text { Q13 } \\
+ \\
14\end{array}$ & $\begin{array}{l}\text { Name of high school attended/Town/city } \\
\text { where school is situated (No fee school=1, } \\
\text { Fee-paying school=2, Private school=3) }\end{array}$ & $\begin{array}{l}1=17 \\
2=35 \\
3=17\end{array}$ & $\begin{array}{l}1=24.6 \\
2=50.7 \\
3=24.6\end{array}$ & $\begin{array}{l}1=21 \\
2=9 \\
3=5\end{array}$ & $\begin{array}{l}1=60 \\
2=25.7 \\
3=14.3\end{array}$ & $.002^{* *}$ \\
\hline Q15 & $\begin{array}{l}\text { Had Accounting as a school subject (yes=1, } \\
\text { no=2) }\end{array}$ & $\begin{array}{l}\mathrm{Y}=49 \\
\mathrm{~N}=20\end{array}$ & $\begin{array}{l}Y=71.0 \\
N=29.0\end{array}$ & $\begin{array}{l}Y=8 \\
N=27\end{array}$ & $\begin{array}{l}\mathrm{Y}=22.9 \\
\mathrm{~N}=77.1\end{array}$ & $.000^{* *}$ \\
\hline Q17 & $\begin{array}{l}\text { Level of English in Grade } 12 \text { (English Home } \\
\text { Language }=1, \quad \text { English First Additional } \\
\text { Language }=2 \text { ) }\end{array}$ & $\begin{array}{l}H L=41 \\
A l=29\end{array}$ & $\begin{array}{l}H L=58.6 \\
\mathrm{AL}=41.4\end{array}$ & $\begin{array}{l}H L=10 \\
A L=25\end{array}$ & $\begin{array}{l}H L=28.6 \\
\mathrm{AL}=71.4\end{array}$ & $.004^{* *}$ \\
\hline Q18 & $\begin{array}{l}\text { Symbol received for English in final exams } \\
(A=7, B=6, C=5, D=4, E=3, F=2)\end{array}$ & $\begin{array}{c}A B=24 \\
C=33 \\
D E F=12\end{array}$ & $\begin{array}{c}\mathrm{AB}=34.8 \\
\mathrm{C}=47.8 \\
\mathrm{DEF}=17.4\end{array}$ & $\begin{array}{c}A B=11 \\
C=10 \\
D E F=14\end{array}$ & $\begin{array}{c}\mathrm{AB}=31.4 \\
\mathrm{C}=28.6 \\
\mathrm{DEF}=40.0\end{array}$ & $.031^{*}$ \\
\hline Q19 & $\begin{array}{l}\text { Symbol received for Maths in final exams } \\
(A=7, B=6, C=5, D=4, E=3, F=2)\end{array}$ & $\begin{array}{c}A B=8 \\
C=8 \\
D=26 \\
F=27\end{array}$ & $\begin{array}{l}A B=11.6 \\
C=11.6 \\
D=37.7 \\
F=39.1\end{array}$ & $\begin{array}{c}A B=19 \\
C=14 \\
D=2 \\
F=0\end{array}$ & $\begin{array}{c}A B=54.3 \\
C=40.0 \\
D=5.7 \\
F=0\end{array}$ & $.000^{*}$ \\
\hline Q20 & $\begin{array}{l}\text { Final AP Score gained (Mean scores } \\
\text { provided) }\end{array}$ & $n=70$ & Mean $=28.20$ & $n=35$ & $\begin{array}{c}\text { Mean= } \\
27.09\end{array}$ & .555 \\
\hline
\end{tabular}

${ }^{* *}$ Significant at $1 \%$ level

*Significant at $5 \%$ level

\section{Comparison of pre-intervention paragraph marks between groups}

It was also necessary to establish similarity of ability between the test and control groups. This was done by comparing the pre-intervention marks between groups. When a variable (in this case the pre-intervention paragraph mark) from two independent samples (in this case the test 
and control groups) needs to be compared, it is suitable to use the parametric two-sample t-test. While the two groups were of unequal size, there was equality of variances. Therefore, this ttest was suitable. The mean scores were 52.09 per cent for the test group and 38.78 per cent for the control group (see Table 3). The p-value of the comparison between the groups was 0.013 , which is statistically significant. The two groups were thus not similar in ability.

Table 3: Results of comparison of pre-intervention paragraph marks for test and control group

\begin{tabular}{|l|c|c|c|c|}
\cline { 2 - 5 } \multicolumn{1}{c|}{} & \multicolumn{4}{|c|}{$\begin{array}{c}\text { Pre-intervention paragraph marks } \\
\text { (compared between groups) }\end{array}$} \\
\cline { 2 - 5 } \multicolumn{1}{c|}{} & $\mathbf{M}$ & SD & $\mathbf{n}$ & p-value \\
\hline Test group & $52.09 \%$ & $25.87 \%$ & 70 & $0.013^{*}$ \\
\hline Control group & $38.78 \%$ & $24.79 \%$ & 35 & \\
\hline
\end{tabular}

*Significant at 5\% level

\section{Comparison of pre- and post-intervention paragraph marks for each group}

Once the comparisons between the groups had been established, the marks obtained for the preand post-intervention paragraphs needed to be evaluated for improvement. Without measuring improvement, it is not possible to draw conclusions about whether concept mapping is an effective scaffolding instrument for the enhancement of concept literacy (Leauby et al. 2010). An improvement in the test group marks would support the effectiveness of concept mapping in improving conceptualisation; however, a similar improvement for the control group would mean that an improvement in marks cannot be attributed to concept mapping.

Paired $t$-tests were used to compare students' paragraph results, both pre- and postintervention. The results of the post-intervention paragraph (see Table 4) were lower than those of the pre-intervention test (see Table 3) for both the test and control groups, and, even though the $\mathrm{p}$-values at $>0.05$ indicated that the drop in marks was not significant, the results were disappointing in light of the aim of this research. These results were, however, in line with previous studies where the quantitative data were found not to support the efficacy of concept mapping in enhancing learning (Leauby et al. 2010).

Table 4: Results of comparison of pre- and post-intervention paragraph marks for test and control group

\begin{tabular}{|l|c|c|c|c|}
\cline { 2 - 5 } \multicolumn{1}{c|}{} & \multicolumn{4}{|c|}{$\begin{array}{c}\text { Post-intervention paragraph marks } \\
\text { (compared to pre-intervention marks) }\end{array}$} \\
\cline { 2 - 5 } \multicolumn{1}{c|}{} & $\mathbf{M}$ & SD & $\mathbf{n}$ & p-value \\
\hline Test group & $46.88 \%$ & $22.81 \%$ & 70 & 0.960 \\
\hline Control group & $33.48 \%$ & $25.66 \%$ & 35 & 0.277 \\
\hline
\end{tabular}




\section{Comparisons between the quantitative pre-intervention questionnaire results and the marks of the two groups}

The questionnaire completed before the intervention was aimed at identifying background variables that could possibly impact on the test results. The Spearman-rho correlation test was used to examine the collinearity between the questionnaire co-variates and the results of the paragraphs (pre- and post-intervention). All significant relationships are summarised in Table 5 and discussed thereafter.

\section{Pre-intervention questionnaire factors that had a significant impact on the pre- intervention paragraph marks for the test group}

In order to establish whether a causal link existed between the pre-intervention questionnaire factors of the test group and the pre-intervention paragraph marks, the General Linear Model (GLM) was used. See Table 5 for a summary of the results. An initial running of the GLM showed that the model was significant, with a p-value $<0.05$, and that the model could therefore be reported. While significance is sought, it is also worth reporting factors that show a tendency towards significance. Two such factors can be reported here. Non-visual students (Q4) and students who were familiar with visual elements (Q5) appear to have been more inclined to get good marks in the pre-intervention paragraph. These results seem contradictory and are not borne out by further results. The factors that showed significance were previous experience of accounting (Q15), completing English (as) Home Language in Grade 12 (Q17) and a high APS (Q20), all having p-values $<0.05$ (see Table 5 above). Students with these attributes were therefore more likely to have good pre-intervention paragraph marks.

\section{Pre-intervention questionnaire factors that had a significant impact on the pre- intervention paragraph marks of the control group}

As the control group only had 35 respondents, it was suitable to use the NPAR1WAY procedure instead of the GLM procedure. The NPAR1WAY procedure is made up of two tests: when one is not expecting normal distribution and the two groups of data are independent, the Wilcoxon rank-sum test is used; however, if the independent variables have three or more categories, the Kruskal-Wallis test is used.

Four factors showed significance: familiarity with visual aids (Q5), its p-value being $<0.05$; type of school attended (derived from Q13), with a p-value $<0.01$; previous experience of accounting $(\mathrm{Q} 15)$, with a p-value $<0.05$; and the level at which English was studied in Grade 12 , with a $p$-value $<0.05$. The fact that previous experience of visual aids appears to have 
Table 5: Table showing significant relationships between pre- and post-intervention paragraph marks and pre-intervention questionnaire variables per group

\begin{tabular}{|c|c|c|c|c|c|c|c|c|c|c|c|c|c|}
\hline \multirow{3}{*}{ No } & \multirow{3}{*}{ Question } & \multicolumn{6}{|c|}{$\begin{array}{l}\text { Test group (BCom) } \\
\text { (GLM procedure) }\end{array}$} & \multicolumn{6}{|c|}{$\begin{array}{c}\text { Control group (BSc) } \\
\text { (Kruskal-Wallis test/ Wilcoxon rank-sum scores) }\end{array}$} \\
\hline & & \multicolumn{3}{|c|}{ Pre-intervention marks } & \multicolumn{3}{|c|}{$\begin{array}{l}\text { Post-intervention } \\
\text { marks }\end{array}$} & \multicolumn{3}{|c|}{ Pre-intervention marks } & \multicolumn{3}{|c|}{$\begin{array}{l}\text { Post-intervention } \\
\text { marks }\end{array}$} \\
\hline & & $\mathbf{n}$ & $\begin{array}{l}\text { Mean } \\
\text { score }\end{array}$ & $\begin{array}{c}\mathrm{p}- \\
\text { value }\end{array}$ & $\mathbf{n}$ & $\begin{array}{l}\text { Mean } \\
\text { score }^{1}\end{array}$ & $\begin{array}{c}\mathrm{p}- \\
\text { value }\end{array}$ & $\mathbf{n}$ & $\begin{array}{l}\text { Mean } \\
\text { rank }\end{array}$ & $\begin{array}{c}\text { p- } \\
\text { value }\end{array}$ & $\mathbf{n}$ & $\begin{array}{c}\text { Mean } \\
\text { rank }\end{array}$ & $\begin{array}{c}\text { p- } \\
\text { value }\end{array}$ \\
\hline \multirow{2}{*}{ Q4 } & \multirow{2}{*}{$\begin{array}{l}\text { I learn by using visual elements (e.g. maps, graphs, } \\
\text { pictures) } \\
\text { (strongly agree=1, agree=2, disagree=3, strongly } \\
\text { disagree=4). }\end{array}$} & $\begin{array}{l}1+2=41 \\
3+4=24\end{array}$ & $\begin{array}{l}6.634 \\
8.083 \\
\end{array}$ & 0.088 & & & & & & & & & \\
\hline & & \multicolumn{3}{|c|}{ Tendency } & & & & & & & & & \\
\hline \multirow{2}{*}{ Q5 } & \multirow{2}{*}{$\begin{array}{l}\text { I have used visual aids, such as the one shown here, } \\
\text { before } \\
\text { (yes=1, no=2). }\end{array}$} & $\begin{array}{l}\mathrm{Y}=44 \\
\mathrm{~N}=21\end{array}$ & $\begin{array}{l}7.659 \\
6.143 \\
\end{array}$ & 0.074 & & & & \multirow{2}{*}{$\begin{array}{l}\mathrm{Y}=15 \\
\mathrm{~N}=20\end{array}$} & \multirow{2}{*}{$\begin{array}{l}22.067 \\
14.950\end{array}$} & \multirow{2}{*}{0.041} & & & \\
\hline & & \multicolumn{3}{|c|}{ Tendency } & & & & & & & & & \\
\hline $\begin{array}{l}\text { Q13 } \\
+14\end{array}$ & $\begin{array}{l}\text { Name of high school attended/Town/city where school } \\
\text { is situated } \\
\text { (No fee school=1, Fee-paying school=2, Private } \\
\text { school=3). }\end{array}$ & & & & & & & $\begin{array}{c}1=9 \\
2=7 \\
3=19\end{array}$ & $\begin{array}{l}21.167 \\
27.214 \\
13.105\end{array}$ & 0.004 & & & \\
\hline Q15 & $\begin{array}{l}\text { Had Accounting as a school subject } \\
\text { (yes }=1, \text { no=2). }\end{array}$ & $\begin{array}{l}Y=45 \\
N=20\end{array}$ & $\begin{array}{l}7.878 \\
5.575\end{array}$ & 0.010 & $\begin{array}{l}\mathrm{Y}=45 \\
\mathrm{~N}=20\end{array}$ & $\begin{array}{l}8.200 \\
5.725\end{array}$ & 0.010 & $\begin{array}{c}Y=8 \\
N=27\end{array}$ & $\begin{array}{l}25.750 \\
15.704\end{array}$ & 0.015 & $\begin{array}{l}\mathrm{Y}=8 \\
\mathrm{~N}=27\end{array}$ & $\begin{array}{l}25.500 \\
15.778\end{array}$ & 0.018 \\
\hline Q17 & $\begin{array}{l}\text { Level of English in Grade } 12 \\
\text { (Home Language=1, First Additional Language=2). }\end{array}$ & $\begin{array}{l}1=40 \\
2=25\end{array}$ & $\begin{array}{l}8.050 \\
5.760\end{array}$ & 0.005 & & & & $\begin{array}{l}1=10 \\
2=25\end{array}$ & $\begin{array}{l}23.800 \\
15.680\end{array}$ & 0.034 & & & \\
\hline Q20 & Final AP Score gained & 65 & 28.2 & 0.008 & & & & & & & & & \\
\hline
\end{tabular}


influenced the pre-intervention paragraph scores of the control group echoes the tendency observed for the test group. However, as with the test group, there is no link between familiarity with visual aids and the post-intervention paragraph scores, and therefore this factor cannot be said to have an impact on results. Students in the control group who attended fee-paying schools were more likely to obtain a good mark in the pre-intervention paragraph. It is an interesting observation that students who attended no-fee schools fared better than those who attended private schools. An explanation for this phenomenon might be the diverse nature of private schools in South Africa. Those students of the control group who had prior knowledge of accounting were more inclined to achieve a good result in the pre-intervention paragraph. This is a similar result to that of the test group. Finally, students in the control group who had taken English as Home Language in Grade 12 were inclined to get good marks for the pre-intervention paragraph. Even though this result again echoes that of the test group, the possible influence that language might have had on learning does not seem to be supported by the post-intervention paragraph scores.

\section{Pre-intervention questionnaire factors that had a significant impact on the post-intervention paragraph marks of the test group}

The only questionnaire variable with an observable effect on the results of the test group postintervention paragraph was whether students had studied accounting previously (Q15), with a p-value of 0.010. Similarly, previous experience of accounting was a significant factor when the impact of pre-intervention questionnaire factors on the pre-intervention paragraph results were investigated.

\section{Pre-intervention questionnaire factors that had a significant impact on the post-intervention paragraph marks of the control group}

As in the case of the test group, prior knowledge of accounting (Q15) was the only factor in the pre-intervention questionnaire that had influenced the post-intervention paragraph results, with a p-value of 0.018 . From this and previous results, we can deduce that previous experience of accounting is the only factor that had an impact on student performance.

\section{The quantitative results of the post-intervention questionnaire}

It was important to find out how the students in the test group had experienced the concept mapping technique, and this was done via a follow-up questionnaire. The FREQ procedure was used to establish a link between the test group's experience of the intervention and the postintervention scores. This procedure produces a simple one-way frequency table. The results are 
reflected in Table 6. Seven of the nine questions contained in the questionnaire were focussed on the concept mapping intervention. The responses to these questions were positive, ranging from 73.91 per cent of respondents who found concept mapping easy to use, to 65.22 per cent who liked concept mapping. Two seemingly unrelated questions were included to cater for the possible influence of negative attitudes towards accounting and the Mamelodi campus. These questions also garnered positive responses (85.51\% and $73.91 \%$ respectively) and showed that there was no general negativity in student attitudes. These overall positive responses after limited exposure to concept mapping are note-worthy.

Table 6: Table showing frequency of post-intervention questionnaire responses for test group

\begin{tabular}{|c|c|c|c|}
\hline No & $\begin{array}{l}\text { Question } \\
\text { (Scaling = strongly agree=1, agree=2, disagree=3, } \\
\text { strongly disagree) }\end{array}$ & $\mathbf{n}$ & $\%$ \\
\hline Q1 & I like Accounting. & $\begin{array}{l}\text { Agree }(1+2)=59 \\
\text { Disagree }(3+4)=10\end{array}$ & $\begin{array}{l}\text { Agree }=85.51 \\
\text { Disagree }=14.49\end{array}$ \\
\hline Q2 & I find concept mapping easy to use. & $\begin{array}{l}\text { Agree }(1+2)=51 \\
\text { Disagree }(3+4)=18\end{array}$ & $\begin{array}{l}\text { Agree }=73.91 \\
\text { Disagree }=26.09\end{array}$ \\
\hline Q3 & $\begin{array}{l}\text { Concept mapping helped me to better UNDERSTAND } \\
\text { the Accounting concepts. }\end{array}$ & $\begin{array}{l}\text { Agree }(1+2)=52 \\
\text { Disagree }(3+4)=17\end{array}$ & $\begin{array}{l}\text { Agree }=75.36 \\
\text { Disagree }=24.64\end{array}$ \\
\hline Q4 & $\begin{array}{l}\text { Concept mapping made it easier to REMEMBER } \\
\text { information. }\end{array}$ & $\begin{array}{l}\text { Agree }(1+2)=52 \\
\text { Disagree }(3+4)=17\end{array}$ & $\begin{array}{l}\text { Agree }=75.36 \\
\text { Disagree }=24.64\end{array}$ \\
\hline Q5 & $\begin{array}{l}\text { Concept mapping helped to identify } \\
\text { MISCONCEPTIONS I had about a topic. }\end{array}$ & $\begin{array}{l}\text { Agree }(1+2)=49 \\
\text { Disagree }(3+4)=20\end{array}$ & $\begin{array}{l}\text { Agree }=71.01 \\
\text { Disagree }=28.99\end{array}$ \\
\hline Q6 & I will use concept mapping again. & $\begin{array}{l}\text { Agree }(1+2)=47 \\
\text { Disagree }(3+4)=22\end{array}$ & $\begin{array}{l}\text { Agree }=68.12 \\
\text { Disagree }=31.88\end{array}$ \\
\hline Q7 & I liked using concept mapping. & $\begin{array}{l}\text { Agree }(1+2)=45 \\
\text { Disagree }(3+4)=24\end{array}$ & $\begin{array}{l}\text { Agree }=65.22 \\
\text { Disagree }=34.78\end{array}$ \\
\hline Q8 & $\begin{array}{l}\text { I would be able to use concept mapping in my other } \\
\text { subjects. }\end{array}$ & $\begin{array}{l}\text { Agree }(1+2)=48 \\
\text { Disagree }(3+4)=21\end{array}$ & $\begin{array}{l}\text { Agree }=69.57 \\
\text { Disagree }=30.43\end{array}$ \\
\hline Q9 & I like being at the Mamelodi campus. & $\begin{array}{l}\text { Agree }(1+2)=51 \\
\text { Disagree }(3+4)=18\end{array}$ & $\begin{array}{l}\text { Agree }=73.91 \\
\text { Disagree }=26.09\end{array}$ \\
\hline
\end{tabular}

\section{CONCLUSION}

Throughput has often been cited as one of the major problems in higher education in South Africa. Numerous government policies have been implemented to address the problem. Academia responded by establishing various academic development programmes. Despite these endeavours no final solution to the problem has been found, although some of the underlying issues have been identified. Rote learning, which is characteristic of the learning and assessment methods of many schools, has resulted in insufficient development of cognitive skills and ultimately of concept literacy. This translates into subjects being inaccessible when students reach university. More research is clearly needed in the search for solutions to this educational dilemma.

Theoretically, this study was embedded in Ausubel's Assimilation Theory (1962), which focuses on the attainment of meaningful learning by means of identifying prior knowledge. This approach requires a commitment to learning from the student and necessitates a classroom 
environment. Concept mapping, pioneered by Novak in 1972, is in turn indebted to Ausubel's Assimilation Theory (1962), as it represents knowledge in a hierarchical structure and is an effective scaffolding tool. The particular scaffolding strategy that was selected was premised on these principles.

The research was conducted at a South African university within an extended course for BCom and BSc students, and was aimed at establishing the effectiveness of using the concept mapping technique in accounting to facilitate concept literacy, by statistically analysing the quantitative results of a pre-intervention questionnaire completed by the test and control groups, a pre- and a post-intervention paragraph written by both groups, and a post-intervention questionnaire completed by the test group. The data were analysed from various angles to ensure objectivity and validity.

When comparing the pre-intervention paragraph marks of the groups, it became evident that they were not equal in ability, contrary to what had been presumed prior to the study. Thereafter, when the marks for each group's pre- and post-intervention paragraphs were compared, a negligible decline was observed. Data on confounding variables, derived from the pre-intervention questionnaire, were tested for possible influence on the pre- and postintervention paragraphs marks. Only one aspect was shown to be significant, namely previous experience of accounting. This result explained the reported difference in ability, as few of the BSc students, who obtained lower marks for the paragraphs than the BCom students, had had accounting as a school subject. From the results discussed here, it is clear that the effectiveness of concept mapping in enhancing concept literacy cannot be confirmed.

Several factors could have had an impact on the validity of the findings of this research study. Firstly, too little time was available in the accounting curriculum for students to become adequately conversant with the concept mapping technique and for the benefits to become apparent. Secondly, the unfamiliar assessment format could have had an adverse effect on the students' marks. Finally, the limited participation of the students had an impact on the numbers available for the research and also indicated a lack of responsibility towards their own learning.

\section{BENEFITS OF CONCEPT MAPPING}

Despite the limitations of this study, it should be reiterated that concept mapping has definite advantages in its ability to scaffold concept literacy. Making use of alternative modes and media enables students with different learning styles and learning preferences to draw on their multiple semiotic repertoires in an increasingly multimodal world. Concept mapping could therefore enhance learning in many learning areas across disciplines in higher education.

The advantages of using concept mapping in higher education can be summarised in the 
following ways: Firstly, the technique allows for large areas of knowledge to be scaffolded by means of graphic representation in which the interrelationships between concepts are made explicit, furthermore making the clarification of complex concepts possible. Secondly, student participation is essential to the completion of a concept map; consequently, students' prior knowledge is established, evidence of meaningful learning is demonstrated and, moreover, misconceptions become evident. When the creation of a concept map is part of a group project, the collaboration required encourages the sharing of collective knowledge. Underprepared students, in particular, may benefit from the structure provided by concept mapping. Thirdly, because of the conceptual understanding that is required for the completion of a concept map, critical thinking is encouraged instead of rote learning. Meta-cognitive skills are therefore encouraged and are also transferred across domains. Concept mapping can thus enhance learning in most learning areas in higher education and especially where surface learning has been found to undermine proficiency in students' chosen disciplines.

The contribution of concept mapping to accounting education is that it allows for other forms of assessment to be used, besides those that are numerically based. Accounting students are not often asked to clarify their understanding of the concepts they use, as was done in the pre- and post-intervention tests in this study. Furthermore, using concept maps to teach accounting concepts will allow educators to assess students' thought processes and understanding of accounting terminology directly.

\section{SUGGESTIONS FOR FUTURE RESEARCH}

Future studies into concept mapping should further interrogate its purported strengths, while at the same time addressing the limitations of this study, for instance by presenting the intervention over a longer period of time. The technique can furthermore be enhanced and made more applicable to the South African context by augmenting concept maps with multilingual terminology and multilingual definitions. The explorative research conducted by Carstens $(2016,210)$ in the domain of Construction Economics, could, for instance, be extended in a quasi-experimental study using three conditions within a single test group: (1) text only, (2) concept maps with English labels and brief conceptual definitions provided in a legend, and (3) multilingual concept maps with labels and conceptual definitions in English, Afrikaans, one Sotho language and one Nguni language.

\section{REFERENCES}

Ausubel, D. P. 1962. A subsumption theory of meaningful verbal learning and retention. The Journal of General Psychology 66: 213-224. https://doi.org/10.1080/00221309.1962 .9711837 
Bureau: Institutional Research \& Planning. 2016. UP by numbers. http://www.universityofpretoria. co.za/en/bureau-for-institutional-research-planning/article/1970929/up-by-numbers (Accessed 23 November 2016).

Boughey, C. 2010. Academic development for improved efficiency in the higher education and training system in South Africa. Southern Africa: Development Bank, Pretoria.

Brennan, L. K., R. C. Brownson, C. Kelly, M. K. Ivey and L. C. Leviton. 2012. Concept mapping: priority community strategies to create changes to support active living. American Journal of Preventive Medicine 43(5 Supplement 4): S337-S350. https://doi.org/10.1016/j.amepre. 2012.07.015

Cañas, A.J., G. Hill, R. Carff, N. Suri, J. Lott, G. Gómez, T.C. Eskridge, M. Arroyo and R. Carvajal. 2004. CmapTools: A knowledge modeling and sharing environment. Concept maps: Theory, methodology, technology: Proceedings of the first international conference on concept mapping. Pamplona, Spain.

Carnot, M. J., P. Feltovich, R. R. Hoffman, J. Feltovich and J. D. Novak. 2003. A summary of literature pertaining to the use of concept mapping techniques and technologies for education and performance support. The Chief of Naval Education and Training. Pensacola, Florida IHMC.

Carstens, A. 2016. Translanguaging as a vehicle for L2 acquisition and L1 development: Students' perceptions. Language Matters 47(2): 203-222. http://dx.doi.org/10.1080/10228195. 2016.1153135

Chabeli, M. M. 2010. Concept-mapping as a teaching method to facilitate critical thinking in nursing education: A review of the literature: Original research. Health SA Gesondheid 15: 1-7. http://dx.doi.org/10.4102/hsag.v15i1.432

Chang, K., Y. Sung and I. Chen. 2002. The effect of concept mapping to enhance text comprehension and summarization. The Journal of Experimental Education 71: 5-23. https://doi.org/10.1080/ 00220970209602054

CHE see Council on Higher Education.

Clarke, S. 2015. Concept mapping. Nursing Standard 30(5): 61-62.

Council on Higher Education. 2013. A proposal for undergraduate curriculum reform in South Africa: The case for a flexible curriculum structure: Report of the task team on undergraduate curriculum structure. Pretoria: Council on Higher Education.

Council on Higher Education. 2015. VitalStats public higher education 2013. Pretoria: Council on Higher Education.

Creswell, J. W. 2014. Research design: Qualitative, quantitative, and mixed methods approaches. $4^{\text {th }}$ Edition. London: Sage Publications, Inc.

Croft, W. and D. A. Cruse. 2004. Cognitive linguistics. Cambridge: Cambridge University Press.

Department of Education. 1997. Education White Paper 3: A programme for the transformation of higher education. Pretoria: Department of Education.

Department of Higher Education and Training. 2010. Strategic Plan 2011-2015. Pretoria: Department of Higher Education and Training.

Department of Higher Education and Training. 2011. Revised Strategic Plan 2010/11-2014/15. Pretoria: Department of Higher Education and Training.

DHET see Department of Higher Education and Training.

Gablasova, D. 2012. "Learning and expressing technical vocabulary through the medium of L1 and L2 by Slovak-English bilingual high-school students." Master's dissertation. University of Auckland.

Greenberg, R. K. and N. A. Wilner. 2015. Using concept maps to provide an integrative framework for teaching the cost or managerial Accounting course. Journal of Accounting Education 33: 16-35. https://doi.org/10.1016/j.jaccedu.2014.11.001

Herrington, J., R. Oliver and T. C. Reeves. 2002. Patterns of engagement in authentic online learning environments. Winds of change in a sea of learning: Proceedings of the 19th Annual ASCILITE 
conference. Auckland, New Zealand.

Herrington, J. A. and A. J. Herrington. 2006. Authentic conditions for authentic assessment: Aligning task and assessment. Critical visions: Thinking, learning and researching in higher education: Research and development in higher education. Milperra, NSW.

Jonker, A. 2016. "The use of multilingual glossaries in enhancing the academic achievement of Extended Degree Programme students in a mainstream subject." Doctoral dissertation. Stellenbosch University, 2016.

Kinchin, I. M. 2000. Concept mapping in Biology. Journal of Biological Education 34: 61-68. https://doi.org/10.1080/00219266.2000.9655687

Leauby, B. A, K. A. Szabat and J. D. Maas. 2010. Concept mapping - An empirical study in introductory financial Accounting. Accounting Education 19: 279-300. https://doi.org/10.1080/ 09639280903412334

Lewin, C. 2011. Understanding and describing quantitative data. In Theory and methods in social research, ed. B. Somekh and C. Lewin, 220-230. $2^{\text {nd }}$ Edition. London: Sage Publications Ltd.

Maas, J. D. and B. A. Leauby. 2005. Concept mapping-exploring its value as a meaningful learning tool in Accounting education. Global Perspectives on Accounting Education 2: 75.

Madiba, M. 2014. Promoting concept literacy through multilingual glossaries: A translanguaging approach. In Multilingual universities in South Africa: Reflecting society in higher education, ed. L. Hibbert and C. van der Walt, 68-87. Bristol: Multilingual Matters.

McKenna, S. 2012. The context of access and foundation provisioning in South Africa. In Alternative access to higher education: Underprepared students or underprepared institutions? ed. R. Dhunpath and R. Vithal, 51-61. Cape Town: Pearsons.

Ministry of Education. 2001. National plan for higher education in South Africa. Pretoria.

Nielsen, L. A. 1980. Comparative evaluation of the cognitive theories of Piaget and Ausubel. Paper presented at the Annual Meeting of the American Reading Conference, Sarasota, Florida, 4-6 December.

Novak, J. D. 2002. Meaningful learning: The essential factor for conceptual change in limited or inappropriate propositional hierarchies leading to empowerment of learners. Science Education 86: 548-571. https://doi.org/10.1002/sce.10032

Novak, J. D. 2010. Learning, creating, and using knowledge: Concept maps as facilitative tools in schools and corporations. $2^{\text {nd }}$ Edition. New York: Routledge.

Novak, J. D. and A. J. Cañas. 2008. The theory underlying concept maps and how to construct and use them. Technical Report IHMC CmapTools. Florida Institute for Human and Machine Cognition. http://cmap.ihmc.us/Publications/ResearchPapers/TheoryUnderlyingConceptMaps.pdf (Accessed 4 July 2017).

Novak, J. D. and D. B. Gowin. 1984. Learning how to learn. Cambridge: Cambridge University Press.

Paxton, M. I. J. 2009. "It's easy to learn when you using your home language but with English you need to start learning language before you get to the concept": Bilingual concept development in an English medium university in South Africa. Journal of Multilingual and Multicultural Development 30: 345-359. https://doi.org/10.1080/01434630 902780731

Pearson, P. D., E. H. Hiebert and M. L. Kamil. 2012. Vocabulary assessment: Making do with what we have while we create the tools we need. In Vocabulary instruction: Research to practice, ed. J. Baumann and E. Kame'enui, 231-255. $2^{\text {nd }}$ Edition. New York, NY: Guilford Press, 231-255.

Pui-lan, K. 2010. Concept mapping. Teaching Theology and Religion 13: 263-265. https://doi.org/10. $1111 /$ j.1467-9647.2010.00625.x

Safayeni, F., N. Derbentseva and A. J. Cañas. 2005. A theoretical note on concepts and the need for cyclic concept maps. Journal of Research in Science Teaching 42: 41-766. https://doi.org/ $10.1002 /$ tea. 20074

Simon, J. 2007. Concept mapping in a Financial Accounting Theory Course. Accounting Education 16: 
273-308. https://doi.org/10.1080/09639280701430306

Somekh, B. and C. Lewin. (Ed.). 2011. Theory and methods in social research. $2^{\text {nd }}$ Edition. London: Sage Publications Ltd.

Trochim, W. M. K. 2001. The research methods knowledge base. $2^{\text {nd }}$ Edition. Cincinnati: Atomic Dog Publishing.

Volbrecht, T. and C. Boughey. 2004. Curriculum responsiveness from the margins? A reappraisal of academic development in South Africa. In Curriculum responsiveness: Case studies in higher education, ed. H, 57-80. Griesel. South African Universities Vice-Chancellors Association.

Vygotsky, L. 1986. Thought and language. Cambridge, Massachusetts: The MIT Press.

Widmayer, S. A. 2005. Schema theory: An introduction. http://www.saber2.net/Archivos/SchemaTheory-Intro.pdf (Accessed 23 November 2016).

Willis, J. W. 2012. Chapter 3: Foundational issues: Postpositivist and critical perspectives. In Foundations of qualitative research: Interpretive and critical approaches, ed. J. Willis and W. Sage. http://methods.sagepub.com.uplib.idm.oclc.org/book/foundations-of-qualitative-research/ n3.xml (Accessed 4 January 2018).

Young, D., J. van der Vlugt and S. Qanya. 2005. Understanding concepts in Mathematics and Science: A multilingual learning and teaching resource book in English, Xhosa, Afrikaans and Zulu. Cape Town: Maskew Miller. 